\title{
Influence of Manganese on the Properties of a Vanadium-bearing Ferritic Stainless Steel
}

\author{
E. M. L. E. M. JACKSON and R. PATON \\ Mintek, Private Bag $X 3015$, Randburg 2125, South Africa.
}

(Received on November 21, 1994; accepted in final form on January 27, 1995)

\begin{abstract}
For the purpose of further increasing toughness, the influence of manganese contents up to $4 \%$ was investigated in a $4 \%$ vanadium-bearing experimental ferritic stainless steel. The tensile and formability properties were also studied. The corrosion properties were measured using electrochemical techniques in $1 \mathrm{~N} \mathrm{H}_{2} \mathrm{SO}_{4}$ and $3.5 \% \mathrm{NaCl}$ solutions.

No marked effect was found on the tensile and formability properties. In contrast, manganese has a strong detrimental effect on the general and localized corrosion properties of this $4 \%$ vanadium alloy. The passivation characteristics in normal sulphuric acid are much poorer. However, spontaneous passivation occurs in this environment where the manganese content is $0.1 \%$. Similarly, the propensity to pitting corrosion is greatly improved at low manganese levels, with pitting potentials superior to both type 304 and 316L stainless steels.
\end{abstract}

KEY WORDS: stainless steels; ferritic; vanadium; manganese; mechanical properties; corrosion properties.

\section{Introduction}

In the past, manganese has been used in carbon-manganese steels ${ }^{1)}$ to achieve grain refining of the ferrite and reduce the grain-boundary carbide thickness, i.e., to improve toughness. In low silicon-steels $(0.01$ to $0.07 \%$ $\mathrm{Si}$, manganese has also been reported to have a significant effect on the impact properties, with a $40^{\circ} \mathrm{C}$ drop in the impact transition temperature. ${ }^{2)}$

In ferritic stainless steels, however, the use of manganese as an alloying addition has been kept to a minimum. In fact, manganese, (like vanadium), is not commonly added to ferritic stainless steels. Manganese is not regarded as a useful alloy addition as such, and American Iron and Steel Institute (AISI) grades specify a maximum limit of $1 \%$ manganese. In the 300 series of stainless steels, manganese additions are allowed up to $2 \%$ maximum, as a useful and more economical austenitizer than nickel. In 1979, Japanese workers ${ }^{3)}$ developed an $18 \% \mathrm{Cr}$ ferritic stainless steel with manganese additions of up to $2 \%$, having improved toughness of sheets and plates in the welded condition. Little effect, however, was observed on the formability of the cold-rolled and annealed sheet product.

Recent work $^{4)}$ has shown the potential of vanadium in improving the impact roughness and localized corrosion performance of an $18 \% \mathrm{Cr}$ ferritic stainless steel. The combined effects of vanadium and manganese on the properties of this material are worthy of investigation.

In this paper, the effects of manganese additions (up to $4 \%$ ) are investigated on the toughness and formability properties of a vanadium-bearing (4\% V) $18 \% \mathrm{Cr}$ ferritic stainless steel in sheet and plate form. Reference to the modified Schaeffler diagram ${ }^{5)}$ shows that up to $4 \%$ manganese can be accommodated in $18 \% \mathrm{Cr}$ ferritic stainless steels without forming austenite. The general and pitting corrosion properties were also examined. In addition, the opportunity was taken to assess the influence of nickel on the $4 \% \mathrm{~V}$ alloy. It is well known in the literature that nickel improves resistance to cleavage fracture in ferrite by increasing the surface energy term $(\tau)$ in the Cottrell-Petch equation:

$$
\left(\sigma_{o} d^{1 / 2}+k_{y}\right) k_{y}=\beta \mu \tau,
$$

where $\beta$ is a constant related to stress state, $\tau$ is the effective surface energy of the crack, $\mu$ is the shear modulus, $d$ is the grain diameter, $\sigma_{o}$ and $k_{y}$ the friction stress and Petch slope respectively. $\left.{ }^{6}\right)$

\section{Experimental Procedure}

Experimental ingots of about $10 \mathrm{~kg}$, and with the chemical composition given in Table 1 , were cast in a vacuum induction furnace. The $(\mathrm{C}+\mathrm{N})$ levels, which markedly influence the toughness of the alloy, were maintained as much as possible within the $200-300 \mathrm{ppm}$ range, which is typical of electric-arc and argon-oxygen decarburization (AOD) practice. The carbon levels, which determine the extent of intergranular corrosion, are within a $50 \mathrm{ppm}$ experimental error.

The ingots were surface-dressed and homogenized at 
Table 1. Experimental alloy compositions.

\begin{tabular}{ccccccccc}
\hline $\begin{array}{c}\text { Alloy } \\
\text { No. }\end{array}$ & $\begin{array}{c}\text { Nominal } \\
\text { Comp. }\end{array}$ & $\begin{array}{c}\mathrm{C} \\
(\mathrm{ppm})\end{array}$ & $\begin{array}{c}\mathrm{Si} \\
(\%)\end{array}$ & $\begin{array}{c}\mathrm{Mn} \\
(\%)\end{array}$ & $\begin{array}{c}\mathrm{Cr} \\
(\%)\end{array}$ & $\begin{array}{c}\mathrm{Mo} \\
(\%)\end{array}$ & $\begin{array}{c}\mathrm{V} \\
(\%)\end{array}$ & $\begin{array}{c}\mathrm{N} \\
(\mathrm{ppm})\end{array}$ \\
\hline 49 & $4 \mathrm{~V}-\mathrm{OMn}$ & 250 & 0.21 & 0.09 & 18.6 & 0.03 & 4.20 & 30 \\
50 & $4 \mathrm{~V}-1 \mathrm{Mn}$ & 200 & 0.31 & 0.97 & 18.6 & 0.03 & 4.14 & 30 \\
51 & $4 \mathrm{~V}-2 \mathrm{Mn}$ & 160 & 0.30 & 2.00 & 18.6 & 0.03 & 4.12 & 40 \\
52 & $4 \mathrm{~V}-3 \mathrm{Mn}$ & 150 & 0.32 & 2.89 & 18.7 & 0.02 & 4.10 & 30 \\
53 & $4 \mathrm{~V}-4 \mathrm{Mn}$ & 140 & 0.30 & 3.89 & 18.6 & 0.02 & 4.10 & 40 \\
80 & $4 \mathrm{~V}-2 \mathrm{Ni}$ & 200 & 0.20 & 0.05 & 18.5 & 0.04 & 3.98 & 30 \\
\hline
\end{tabular}

Balance $\mathrm{Fe}$; residuals $(\mathrm{Cu}, \mathrm{Ni}$, etc. $) 0.1$ max. total; $\mathrm{S}+\mathrm{P} 0.02$ max.

$1100^{\circ} \mathrm{C}$ for $2 \mathrm{~h}$, then hot-rolled to 12 and $6 \mathrm{~mm}$ thick plates, with a $30 \%$ reduction per pass. For all alloys, the finish hot-rolling temperature was around $900-950^{\circ} \mathrm{C}$; the plates were then air-cooled. For sheet processing, hot-rolling to a $4 \mathrm{~mm}$-thick plate material was carried out, with a finish hot-rolling temperature of $900-950^{\circ} \mathrm{C}$, followed by spray quenching to a simulated coiling temperature of $700^{\circ} \mathrm{C}$, and then slow cooling in a vermiculite bed. Intermediate annealing of the $4 \mathrm{~mm}$ plates was done at $815^{\circ} \mathrm{C}$ for $30 \mathrm{~min}$, and followed by water quenching. The annealed and pickled plates were cold rolled to $1 \mathrm{~mm}$ thickness (about $75 \%$ reduction). Sub-size $(5 \times 10 \times 55 \mathrm{~mm})$ T-L [ASTM E399-83] Charpy specimens and $(100 \times 20 \times 10 \mathrm{~mm})$ fracture-toughness bend test specimens were cut from the 6 and $12 \mathrm{~mm}$ thick plate material respectively, annealed at $850^{\circ} \mathrm{C}$ for $30 \mathrm{~min}$, water quenched, and then notched in the case of Charpy specimens. Although this heat treatment may not be optimum, it is based on sub-critical annealing of type 340 stainless steel. ${ }^{3,4,7)}$

Standard tensile test specimens ( $50 \mathrm{~mm}$ gauge length), Erichsen, and Swift test specimens were also cut from the $1 \mathrm{~mm}$ thick sheet material, and final-annealed at $850^{\circ} \mathrm{C}$ for $30 \mathrm{~min}$ and water quenched.

Metallographic examination of the samples was carried out on annealed material cut from the Charpy and tensile specimens. The polished longitudinal sections were electrolytically polished in concentrated $\mathrm{HNO}_{3}$ to reveal carbides and grain boundaries.

Potentiodynamic scans were performed on each alloy using a potentiostat system and a PARC-273 corrosionmeasurement system. A conventional three-electrode system was used. The test specimens were ground to a 1200 grit finish using silicon carbide papers, and washed with acetone prior to the testing. Test solutions of $1 \mathrm{~N}$ $\mathrm{H}_{2} \mathrm{SO}_{4}$ and $3.5 \% \mathrm{NaCl}$ were prepared from reagentgrade chemicals and distilled water. The solutions were purged with high-purity nitrogen gas for at least one hour before each test was started, and continuously throughout the measurement period.

In order to avoid the formation of crevices, which would interfere with the pitting-potential measurements, a modified electrode holder, based on the Avesta pitting cell, ${ }^{8)}$ was used for all cyclic polarization scans. A fast scan rate of $7.2 \mathrm{~V} / \mathrm{h}$ was used for the tests in sulphuric acid and the pitting tests in chloride media (Some of the more promising alloys were retested at the slow rate which conforms to ASTM G61 i.e. $0.72 \mathrm{~V} / \mathrm{h}$.). All the potential values quoted in this work are with respect to

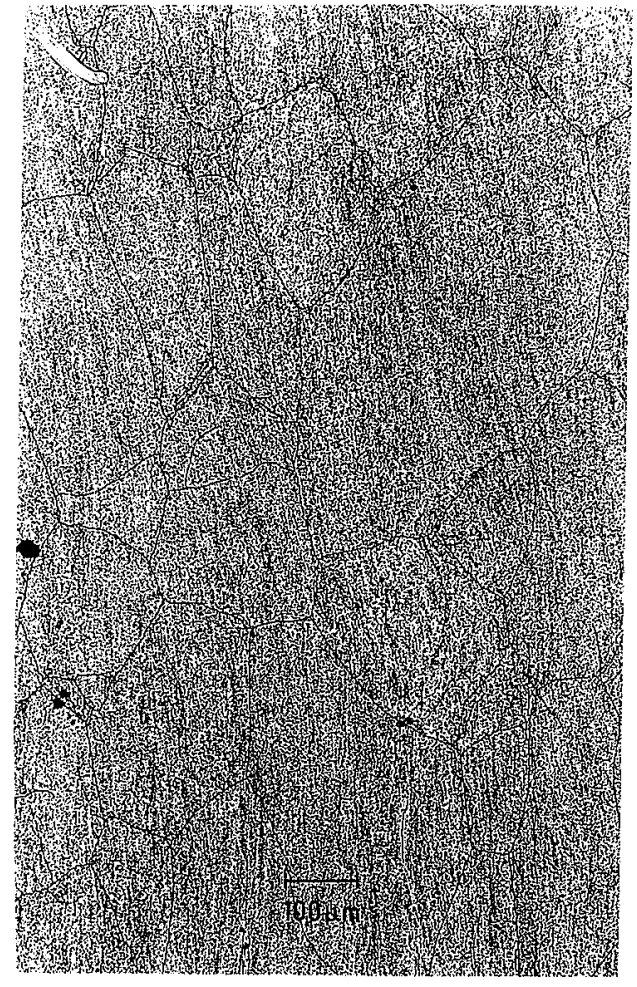

Fig. 1. Microstructure of the $3 \% \mathrm{Mn}$ vanadium-bearing plate alloy (No. 52). Note the formation of sub-grains and fine dispersion of intragranular carbides. ASTM 1 to 2.

the saturated calomel electrode.

\section{Results and Discussion}

\subsection{Microstructure}

The plate alloys containing 3 and $4 \%$ manganese (Nos. 52 and 53 respectively) showed a fully ferritic microstructure with elongated grains indicating a recovery process only and not recrystallization. Similar features to those found in previous work ${ }^{4}$ were present, i.e. sub-grain formation, fine dispersion of intragranular carbides, and an ASTM grain size of 1 to 2 (Figs. 1 and 2). In contrast, recrystallization was more evident in the 1 and $2 \%$ manganese alloys (Nos. 50 and 51 respectively) with more equiaxed and uniform grains and an ASTM grain size of about 4 (Figs. 3 and 4). All the sheet alloys exhibited a recrystallized microstructure, with a mixed grain size in some cases. An example for the $4 \%$ manganese alloy (No. 53) is shown in Fig. 5.

\subsection{Mechanical Properties}

Since the focus of attention was on the impact and fracture toughness of the plate material, only these are discussed here. The effect of manganese additions on the impact toughness of the alloys were assessed from the transition curves shown in Fig. 6. A graph of the Ductile-to-Brittle Transition Temperature (DBTT) as a function of manganese content is shown in Fig. 7 (35 Joule criterion). Due to experimental scatter, a temperature interval is quoted for the DBTT. It can be seen that, with the exception of the $3 \% \mathrm{Mn}$ alloy (No. $52)$, the DBTT increases with manganese content. The DBTT for alloy No. 52 (Fig. 6) show an exceptionally 


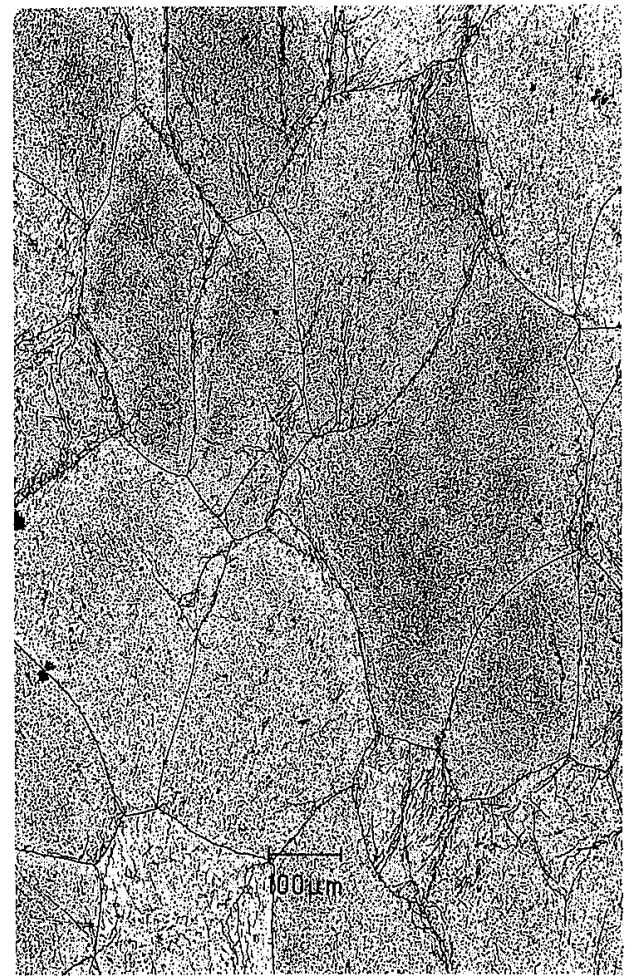

Fig. 2. Microstructure of the $4 \% \mathrm{Mn}$ vanadium-bearing plate alloy (No. 53). As in Fig. 1.



Fig. 3. Microstructure of the $1 \% \mathrm{Mn}$ vanadium-bearing plate alloy (No. 50). Recrystallization is marked by more equiaxed and uniform grains. ASTM about 4.

large scatter. Nickel has a negligible influence on the DBTT for the $4 \% \mathrm{~V}$ alloy (No. 80). Nickel reduces the amount of grain boundary precipitation by trapping interstitial atoms in the lattice, ${ }^{9)}$ whereas vanadium removes chromium carbides at the grain boundaries and

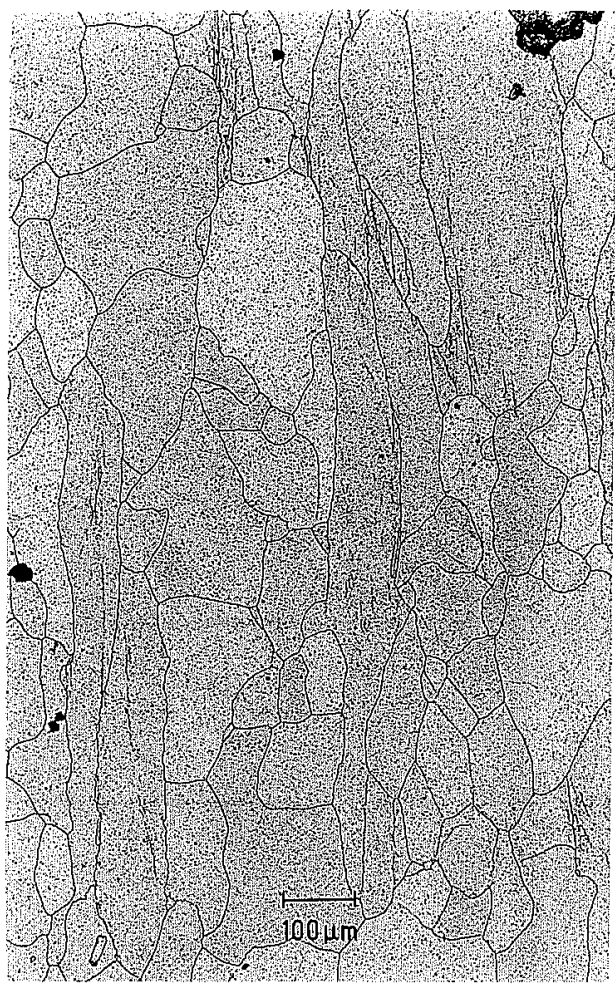

Fig. 4. Microstructure of $2 \% \mathrm{Mn}$ vanadium-bearing plate alloy (No. 51). As in Fig. 3.

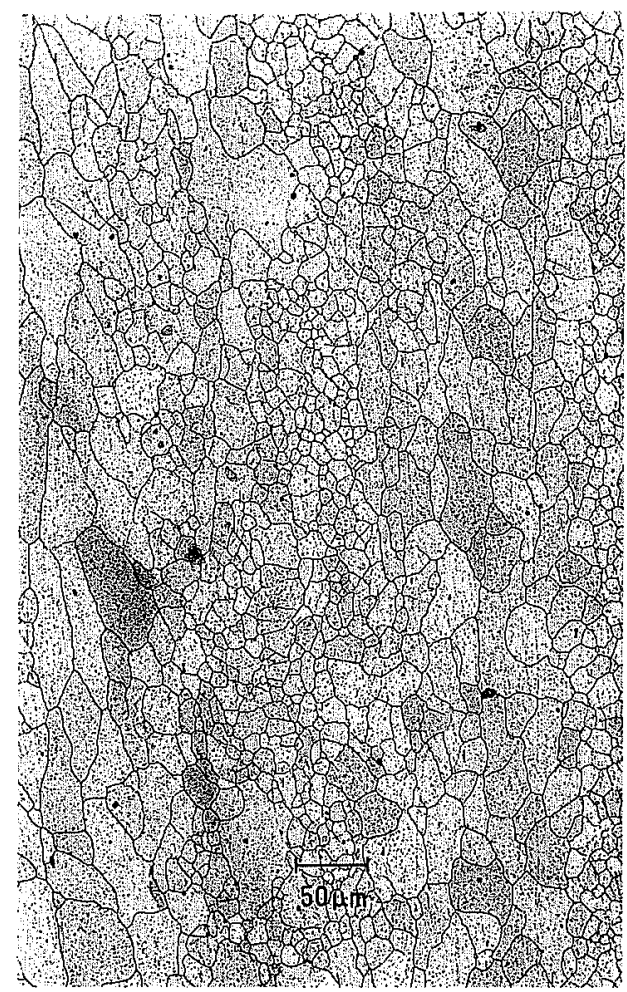

Fig. 5. Recrystallized microstructure obtained from the $4 \%$ $\mathrm{Mn}$ vanadium-bearing sheet alloy.

precipitates vanadium carbides within the grain. ${ }^{10)} \mathrm{It}$ is possible that if nickel reduces the amount of grainboundary precipitates, then no improvement is gained by adding nickel to vanadium-bearing alloys. ${ }^{9)}$

The influence of grain size on the DBTT is well known, and this may have some effect on the results. However, 
ISIJ International, Vol. 35 (1995), No. 5

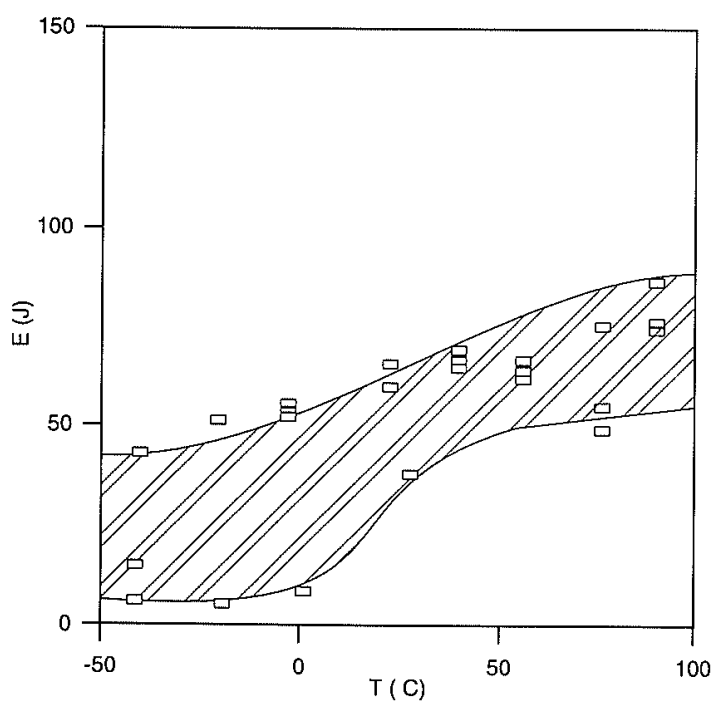

(a)

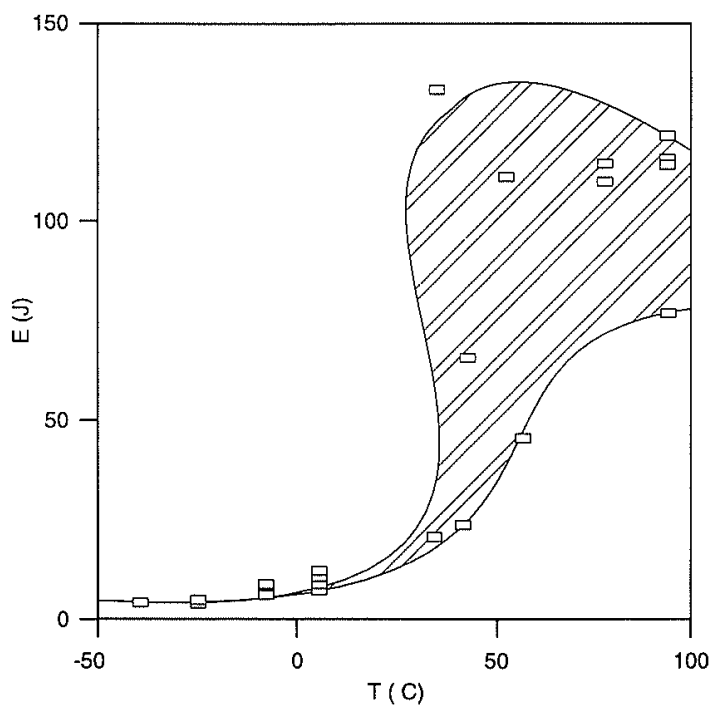

(c)

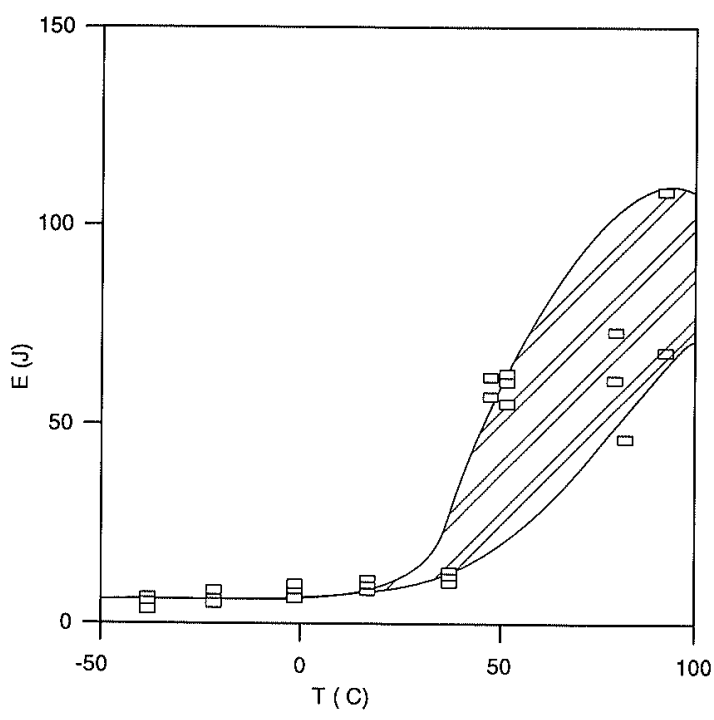

(e)

the effect of stabilizer precipitates (vanadium carbonitrides), in particular their size and distribution, may be more important. ${ }^{11)}$ Cracked precipitates are suitable initiation sites for brittle fracture. In the presence of

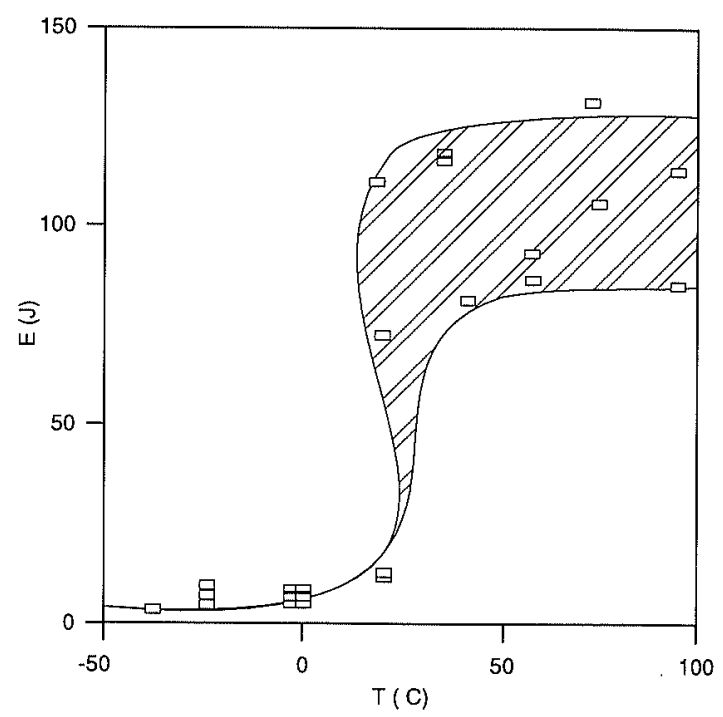

(b)

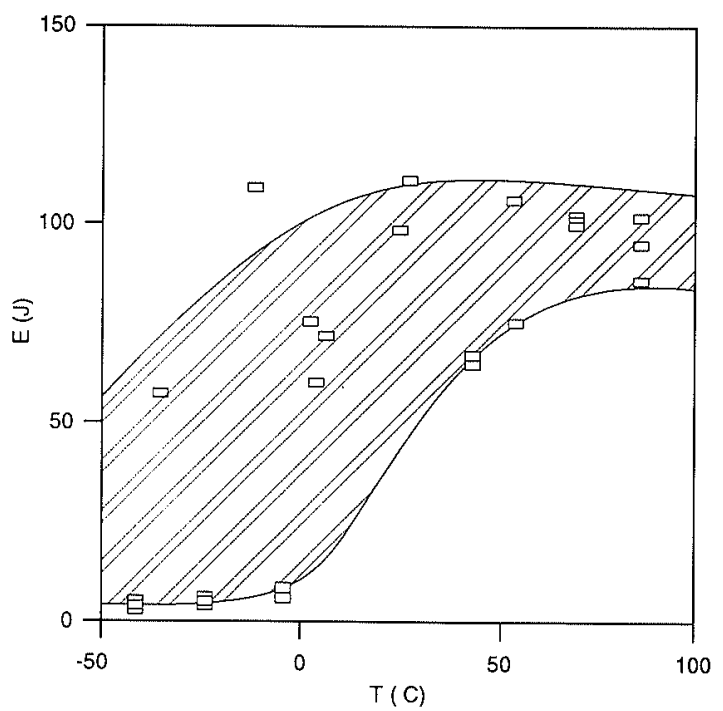

(d)

Fig. 6. Impact energy transition curves for $4 \% \mathrm{~V}$ alloy as a function of Mn content. (a) $0 \%$ (No. 49), (b) $1 \%$ (No. 50), (c) $2 \%$ (No. 51 ), (d) $3 \%$ (No. 52), (e) $4 \%$ (No. 53 ).

vanadium, the observed detrimental effects of manganese may be due to the hardening of the ferrite matrix (Table 2).

The plane-strain fracture-toughness tests $\left(\mathrm{K}_{1 \mathrm{c}}\right)$ show- 




Fig. 7. DBTT (35J) variation with $\mathrm{Mn}$ content for $4 \%$ vanadium alloy.

Table 2. Sheet formability data (results averaged over three 'measurements).

\begin{tabular}{|c|c|c|c|c|c|c|c|c|}
\hline $\begin{array}{l}\text { Alloy } \\
\text { No. }\end{array}$ & $\begin{array}{c}\text { Proof } \\
\text { stress } \\
0.2 \% \\
(\mathrm{MPa})\end{array}$ & $\begin{array}{l}\text { Vickers } \\
\text { HV30 }\end{array}$ & $r^{1)}$ & $n^{2)}$ & $\begin{array}{c}\text { UTS } \\
(\mathrm{MPa})\end{array}$ & $\begin{array}{c}\text { Elong } \\
(\%)\end{array}$ & $\begin{array}{l}\text { Erichsen } \\
(\mathrm{mm})\end{array}$ & $\mathrm{LDR}^{3)}$ \\
\hline 49 & 287 & 165.7 & 0.86 & 0.22 & 460 & 26 & 9.2 & 2.0 \\
\hline 50 & 308 & 152.9 & 0.79 & 0.23 & 473 & 28 & 9.9 & 2.0 \\
\hline 51 & 309 & 154.1 & 0.87 & 0.22 & $48 \mathrm{I}$ & 27 & 9.8 & 2.2 \\
\hline 52 & 321 & 164.5 & 0.67 & 0.22 & 480 & 27 & 10.3 & 2.0 \\
\hline 53 & 323 & 173.5 & 0.84 & 0.23 & 475 & 24 & 10.1 & 2.0 \\
\hline
\end{tabular}

1) Plastic anisotropy factor measured only in longitudinal direction at $15 \%$ strain.

2) Work hardening index calculated for the strain range 0.05 to 0.15 .

3) Limiting draw ratio.

ed no trend with increasing manganese, and were in the range $30-50 \mathrm{MPa} \sqrt{\mathrm{m}}$ which is similar to those from previous work on vanadium additions to $18 \% \mathrm{Cr}$ ferritic stainless steels. ${ }^{4)}$ The main benefit of vanadium as an alloying addition is increased resistance to crack initiation. Fracture is initiation-controlled in these relatively low-strength steels, and the size and distribution of vanadium carbonitride particles decreases the tendency to brittle fracture. Further alloying with manganese or nickel in the presence of vanadium im proves neither the impact toughness nor (in the case of manganese) the fracture toughness.

The mechanical and formability data for the alloy in sheet form are shown in Table 2. The proof stress increases slightly with increasing manganese, probably due to solid-solution hardening. The elongation values fit into a scatter band of 25 to $30 \%$ which is fairly typical of $18 \% \mathrm{Cr}$ steels. The work-hardening indices average around 0.23 , which is fairly typical of steels with a ferrite matrix. A slight increase in the Erichsen value is noticeable with increasing manganese, but in general the addition of manganese causes little change.

\subsection{Corrosion Properties}

Although ferritic stainless steels are not designed for application in $\mathrm{H}_{2} \mathrm{SO}_{4}$, anodic polarization tests were carried out in this medium to serve as a measure of the general corrosion performance of the material in other
Table 3. Anodic polarization data in de-aerated $1 \mathrm{~N} \mathrm{H}_{2} \mathrm{SO}_{4}$ at $25^{\circ} \mathrm{C}$.

\begin{tabular}{rrrrrrr}
\hline $\begin{array}{c}\text { Alloy Scan rate } \\
\text { No. }(\mathrm{mV} / \mathrm{min})\end{array}$ & $\begin{array}{c}E_{\text {corr }} \\
(\mathrm{mV})\end{array}$ & $\begin{array}{c}i_{\text {corr }} \\
\left(\mu \mathrm{A} / \mathrm{cm}^{2}\right)\end{array}$ & $\begin{array}{c}i_{\text {crit }} \\
\left(\mu \mathrm{A} / \mathrm{cm}^{2}\right)\end{array}$ & $\begin{array}{r}E_{\text {pass }} \\
(\mathrm{mV})\end{array}$ & $\begin{array}{c}i_{\text {pass }}(\mathrm{min} .) \\
\left(\mu \mathrm{A} / \mathrm{cm}^{2}\right)\end{array}$ \\
\hline 49 & 12 & +10 & - & - & - & 6.8 \\
50 & 120 & -544 & 795 & 71210 & -399 & 30.6 \\
51 & 120 & -546 & 980 & 80940 & -382 & 32.7 \\
52 & 120 & -546 & 1350 & 88280 & -404 & 73.4 \\
53 & 120 & -582 & 185 & 40380 & -436 & 118.5 \\
$316 \mathrm{~L}$ & 12 & -301 & 4 & 11 & -265 & 2.7 \\
\hline
\end{tabular}

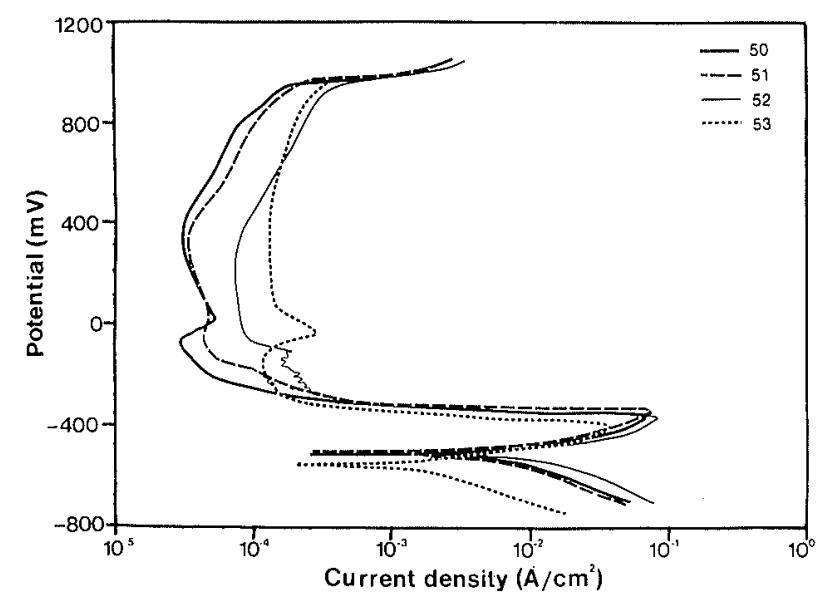

Fig. 8. Anodic polarization curves for $18 \mathrm{Cr}-4 \mathrm{~V}$ stainless steels in $1 \mathrm{~N} \mathrm{H}_{2} \mathrm{SO}_{4}$ at $25^{\circ} \mathrm{C}$, showing the effect of manganese.

environments. The results are given in Table 3.

Previous work ${ }^{12)}$ showed that the $i_{\text {crit }}$ values decrease somewhat with increasing vanadium content. These results indicate an increase in both the passivating tendencies and the active-state corrosion resistance of the stainless steel alloys. ${ }^{13)}$ The addition of manganese however, does not show an effect on the $i_{\text {crit }}$ values at the levels studied. The detrimental influences of manganese on $i_{\text {pass }}(\mathrm{min})$ can be clearly seen in Fig. 8. Passivation in $\mathrm{H}_{2} \mathrm{SO}_{4}$ will be difficult (if not impossible) in practive, due to the $i_{\text {crit }}$ values measured for alloys 50-53. This is evident in high active corrosion rates $(5-9 \mathrm{~mm} / \mathrm{y})$ where $i_{\text {corr }}$ was measured from the Tafel slope using the slow scan method. The results obtained on a type $316 \mathrm{~L}$ austenitic stainless steel are also shown in Table 3 for comparison.

The $4 \% \mathrm{~V}-\mathrm{O} \% \mathrm{Mn}$ alloy (No. 49 ) does not show any anodic peak with its $E_{\text {corr }}$ in the passive range. This result was again confirmed in further tests, and Fig. 9 shows this effect. Spontaneous passivation in $1 \mathrm{~N} \mathrm{H}_{2} \mathrm{SO}_{4}$ has been reported ${ }^{14)}$ for a $18 \% \mathrm{Cr}$ ferritic with the addition of $8 \% \mathrm{Mo}$. In this study, spontaneous passivation can be ascribed to the favourable combination of $4 \%$ vanadium and a low manganese content $(0.1 \%)$. In this case, there may be a sharp decrease in $i_{\text {crit }}$ values as the manganese level is lowered below $1 \%$. This increase of $i_{\text {crit }}$ values as the manganese level is lowered below $1 \%$. This increase of $i_{\text {crit }}$ with increasing manganese has been reported for austenitic stainless steels. ${ }^{13,15)}$ Further work is required to clarify the combined effects of vanadium, 


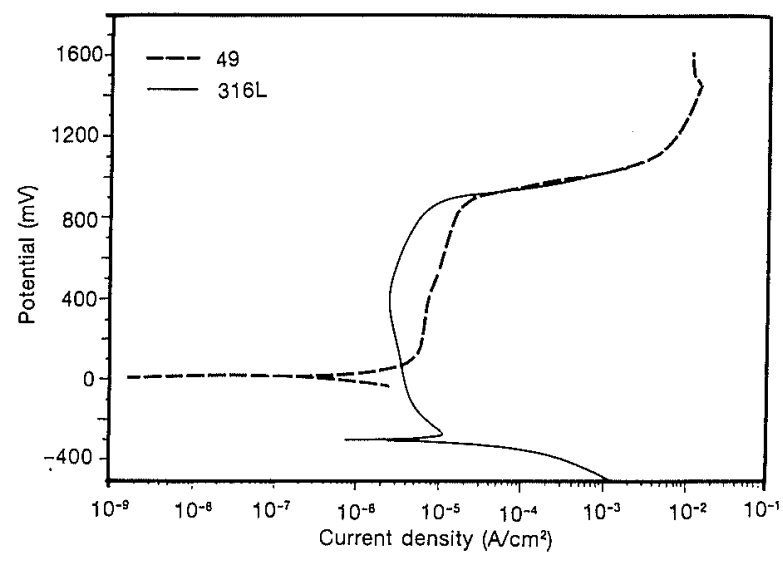

Fig. 9. Anodic polarization curves for $18 \mathrm{Cr}-4 \mathrm{~V}-0 \mathrm{Mn}$ (alloy No. 49) and type $316 \mathrm{~L}$ stainless steel in $1 \mathrm{~N} \mathrm{H}_{2} \mathrm{SO}_{4}$ at $25^{\circ} \mathrm{C}$.



Fig. 10. Variation of the pitting potential with Mn content for $4 \% \mathrm{~V}$ alloys.

Table 4. Cyclic polarization data $\left(3.5 \% \mathrm{NaCl}\right.$ at $25^{\circ} \mathrm{C}$, fast scan rate).

\begin{tabular}{cccc}
\hline Alloy No. & $E_{\text {pit }}(\mathrm{mV})$ & $E_{\text {prot }}(\mathrm{mV})$ & $E_{\text {corr }}(\mathrm{mV})$ \\
\hline 49 & 776 & 429 & -148 \\
50 & 431 & 314 & -137 \\
51 & 404 & 350 & -143 \\
52 & 410 & 355 & -148 \\
53 & 381 & 262 & -123 \\
$316 \mathrm{~L}$ & 324 & -74 & -190 \\
$0.4 \mathrm{Mn}^{*}$ & 558 & 144 & -203 \\
\hline
\end{tabular}

* Composition: $\mathrm{Cr}, 18.4 ; \mathrm{V}, 4.05 ; \mathrm{Mn}, 0.42 ; \mathrm{C}, 250 \mathrm{ppm} ; \mathrm{N}, 40 \mathrm{ppm}$.

manganese, and molybdenum in an $18 \% \mathrm{Cr}$ ferritic stainless steel. In practice, passivation for this alloy is possible even in relatively stagnant solutions. Figure 9 also shows that the type $316 \mathrm{~L}$ stainless steel has a lower passive current density. This is ascribed to its much higher content of alloying elements.

The results of the pitting scans in $3.5 \%$ sodium chloride are shown in Table 4 and Fig. 10. A $400 \mathrm{~g}$ melt at a manganese level of $0.4 \%$ was manufactured to obtain an extra data point. Although the fast scan rates chosen will have an influence on the measured pitting potentials, it is assumed that there is no change in the ranking of the alloys. Again the beneficial effect of low manganese $(0.1 \% \mathrm{Mn}$ for alloy No. 49$)$ can be seen. The $4 \% \mathrm{~V}-$
$0 \% \mathrm{Mn}$ alloy (No. 49 ) displays pitting potentials superior to type 316L stainless steel (slow scan values of $683 \mathrm{mV}$ for alloy No. 49 as against $487 \mathrm{mV}$ for $316 \mathrm{~L}$ ). It is known that vanadium sulphides are far more insoluble in acids than manganese sulphides, ${ }^{16)}$ and this may render pit initiation more difficult. It is possible that the manganese content of the alloy could be low enough for vanadium to substitute almost completely in the sulphide inclusion composition, thereby increasing the pitting potential. Ideally, the manganese content should be limited for optimum corrosion properties in these vanadium-bearing ferritic stainless steels.

Types 304 and 316 austenite stainless steels may suffer premature failure due to pitting, stress-corrosion cracking (SCC), or corrosion fatigue (CF). These failure modes can occur in relatively mild or moderate environments where chlorides (or other halide ions) are present. A cheaper vanadium-bearing stainless steel may prove more cost-effective in such environments. Also, due to its relatively high pitting potential, the vanadium steel may prove a better choice than type 316 in architectural applications, e.g. stainless steel panelling. Success in these applications may lead to increased acceptance of vanadium-bearing stainless steels in the marketplace.

\section{Conclusions}

The main conclusions obtained from this work are as follows.

(1) In $4 \%$ vanadium alloys, the DBTT follows an increasing trend with manganese content.

(2) The addition of $2 \%$ nickel to a manganese-free $4 \% \mathrm{~V}$ alloy caused little change to the DBTT.

(3) Manganese has no marked effect on the tensile and formability parameters.

(4) In contrast, manganese has a strong detrimental effect on the general and localized corrosion properties.

(5) A low-manganese $(<0.1 \%) 4 \% \mathrm{~V}$ ferritic stainless steel has superior corrosion performance to the commercial $18 \% \mathrm{Cr}$ austenitic stainless steels.

(6) Major improvements to the pitting potential are obtained if the manganese level is kept below 0.2 to $0.3 \%$.

\section{Acknowledgment}

This paper is published by permission of Mintek. The authors thank Mr. J. Maskrey (alloy manufacture), Mr. C. J. Fletcher (mechanical testing), and Mr. B. Griesel (corrosion testing) for their valuable assistance.

\section{REFERENCES}

1) B. Mintz and J. Kolahi-Aval: Metall. Trans. A, 19A (1988), 1481.

2) B. Mintz: Met. Technol., (1974), 226.

3) S. Kado, T. Yamazaki, T. Sakamoto, Y. Nakagawa, S. Inoue, S. Izumi, T. Ashiura and S. Uchida: Trans. Iron Steel Inst. Jpn., 19 (1979), 315.

4) K. Premachandra and R. Paton: Innovation Stainless Steel Conf. Proc., Florence, Vol. 3, Associazone Di Metallurgia, Milan, Italy, (1993), III.

5) J. Stanko and D. Wellbeloved: Manganese in corrosion-resistant steels, Report Samancor Ltd., Johannesburg, South Africa, (1991), 10.

6) R. E. Smallman: Modern Physical Metallurgy, 3 ed., But- 
ISIJ International, Vol. 35 (1995), No. 5

terworths, London, (1970), 469.

7) K. Miyakusu, Y. Uematsu and K. Hoshino: Trans. Iron Steel Inst. Jpn., 26 (1986), 228.

8) R. Qvarfort: Corr. Sci., 28, (1988), 135.

9) A. Plumtree and R. Gullberg: Influence of Interstitial and Some Substitutional Alloying Elements in Toughness of Ferritic Stainless Steels, ASTM STP 706, ed. by R. A. Lula, ASTM Philadelphia, U.S.A., (1980), 34.

10) K. Nohara and A. Ejima: Kawasaki Steel Giho, 17 (1985), No. 3,323 .
11) S. Yamamoto, Y. Kobayashi, M. Katahira, T. Takano, M. Takeshita and T. Nagamine: Nippon Kokan Tech. Rep. Overseas, 52, (1988), 17.

12) R. D. Davies, C. G. Gross, P. van Biljon and F. P. A. Robinson: Speciality Steels and Hard Materials Conf. Proc., Pretoria Pergamon Press, Oxford, England, (1982), 329.

13) N. D. Greene and B. E. Wilde: Corrosion-NACE, 26 (1970), 533.

14) M. B. Rockel: Corrosion-NACE, 29 (Oct., 1973), 393.

15) L. Troselius: Corr. Sci., 11 (1971), 473.

16) A. J. Sedriks: Int. Met. Rev., 28 (1983), 295. 